\title{
Integrating information for more productive social housing
}

\section{outcomes: An Australian perspective}

\author{
Judy A. Kraatz, Annie Matan and Peter Newman
}

Introduction

The United Nations Economic Commission for Europe (UNECE) broadly states that social housing is housing 'supplied at prices that are lower than the general housing market and ... distributed through administrative procedures ... some form of state support and subsidy are inevitably involved with this tenure' (Rosenfeld, 2015). Based on the Australian Productivity Commission's definition, social housing can be described as 'below-market rental housing for people on low incomes and for those with special needs', most of which is 'highly subsidised and rent is determined by tenant income (generally set at 25 or $30 \%$ of household income)' (Yates, 2013). In Canada, social housing is

an umbrella term to refer to all forms of housing developed under various government subsidy programs in both the private and public sectors. It includes housing now discontinued under the public housing program, all housing that is owned and operated by the federal, provincial, territorial and municipal governments, and housing that has been subsidized by the government and developed by a private and/or non-profit organization.

(Moskalyk, 2008) 
In the Netherlands, 'the principal target group are low-income households (e.g. families with an income below 29,000 Euros/year).1 The cheaper rented housing is intended primarily for this group, which gets housing benefits from the government' (Aedes, 2016). In the United Kingdom (UK),

Social rented housing is owned by local authorities and private registered providers (as defined in section 80 of the Housing and Regeneration Act 2008), for which guideline target rents are determined through the national rent regime. It may also be owned by other persons and provided under equivalent rental arrangements to the above, as agreed with the local authority or with the Homes and Communities Agency.

(UK Department of Communities and Local Government, 2012)

And in the United States (US),

Public housing was established to provide decent and safe rental housing for eligible low-income families, the elderly and persons with disabilities. Public housing comes in all sizes and types, from scattered single family houses to high rise apartments for elderly families.

(US Department of Housing and Urban Development, 2016)

It should be noted that national terms for this provision vary, including, for example, social housing in Canada, Australia, the Netherlands and the UK; public housing in the US and Israel; common housing in Denmark; and housing promotion in Germany. 
The effective and appropriate provision of social housing, as an integral part of the housing continuum, is increasingly difficult in light of current fiscal constraints and increasing housing needs being experienced globally, especially since the global financial crisis (GFC) of 2007-09. Achieving an economically and socially sustainable framework for the provision of social housing, as part of addressing the pressing need for affordable housing, is vital. To meet this challenge, many innovative models are being explored internationally, including partnerships and financing arrangements involving a mix of public, private and third-sector community provider funds.

The case study that will be presented in later sections of this chapter focuses on establishing clear links between social housing and improving economic productivity as well as non-economic benefits for the tenant, the government and the country as a whole. The Australian Council of Social Services notes this link:

Housing, affordability and location are integral to enabling population growth, and labour mobility, supporting improvements in participation rates and improving productivity. The housing and construction industries are also key drivers of economic activity, and associated jobs growth.

(Australian Council of Social Services, 2014)

The integral role of housing in broader social and economic outcomes is again highlighted by the UNECE. 
Housing is an integrative good, it is linked to many other sectors such as: health, economic security, energy security, transportation, education, employment. Housing also influences issues such as social cohesion and neighbourhood security. As an aggregate part of development efforts, housing is a key element in delivering sustainable urban development. The integrative nature of housing requires the social, cultural, environmental and economic facets of housing to be addressed in an integrated way.

(Rosenfeld, 2015)

This chapter will explore the need for horizontal and vertical integration of data, information and knowledge within and across departments and organisations (both for-profit and not-for-profit) to provide a more comprehensive rationale for a sustainable social housing system. It will do so from an Australian perspective, exploring and discussing the integration required to determine the broad spectrum of social housing benefits and outcomes from this productivity perspective. It will present a case study of a multi-agency collaboration to better portray the wholeof- society and whole-ofgovernment productivity benefits of providing safe and secure social housing.

\section{The social housing sector}

The scale of social housing provision and need is substantial. In Canada, 'the social and affordable housing sector comprises about 4-5 per cent of the total' housing sector in that country (Carlson, 2014), while in the UK this figure is 19 per cent (Bourne, 2016). In the US, there are 1.2 million households living in public housing units (US Department of Housing and Urban Development, 2016). In the Netherlands, social housing organisations provide 2.4 million houses for four million people; 
out of a total national population of 16.8 million (Aedes, 2016). In 2010 in France, about ten million people or 17.3 per cent of the French population were tenants of social housing units (Wong and Goldblum, 2016). As of June 2013, around 414,000 households in Australia, from a total population of approximately 23.1 million, were living in social housing (Department of the Prime Minister and Cabinet, 2014).

It should be noted that some of the variation between the level of provision in various countries can be attributed to the approach taken, both historically and currently, to the provision of housing. The UNECE identifies three categories of social housing, namely: 'universal' which provides social housing to anyone, regardless of their income; 'targeted', where social housing is allocated based on pre-defined income levels; and 'residual', which allocates housing only to those of greatest need (Rosenfeld, 2015). Rosenfeld notes that residual allocation is dominant in many UNECE member states as well as in other countries such as Australia. This 2015 report draws upon an extensive review of the literature from over 50 countries and 30 interviews from a cross-section of representatives. As such it provides a credible backbone for much of the following discussion.

Beyond what is currently provided, significant waiting lists exist for social housing. In the UK, the waiting list was 1.8 million in 2014, up 81 per cent since 1997; in France, there were 1.7 million applications for social housing in 2014; in the US, there was a shortfall of 5.3 million affordable housing units in 2013 (Rosenfeld, 2015). In Australia in June 2013, there were 158,971 applicants on the public rental housing waiting list (Australian Institute of Health and Welfare, 2014). While in Canada, as reported prior to the 2015 national election in that country, there were 140,000 families awaiting rent-subsidised housing (Young, 2015). 
Adequate housing is also a basic necessity and human right which impacts on education, health and employment outcomes, as well as the overall wellbeing of the population. Having a private place to be which is decent and over which we have some real control is fundamental to the well-being of every one of us as individuals and communities. In this sense, affordable housing is both vital economic and social infrastructure.

(Australian Council of Social Service, 2014)

The degree of subsidisation of social housing rent is typically determined by tenant income. In Australia, this is generally set at 25 or 30 per cent of household income (Yates, 2013), while in the US this is 10-30 per cent (US Department of Housing and Urban Development, 2016). In the Netherlands, social housing organisations 'set their own rent policy within the limits of the national rent regulations. On average, social rent levels are approximately 30 percent below the maximum permitted rent' (Aedes, 2016).

\section{The social housing sector in Australia}

This sector in Australia includes public housing, community housing, as well as state-owned and managed Aboriginal and Torres Strait Islander (ATSI) housing (Romans, 2014). As of June 2013, around 414,000 households across the country were living in social housing. General housing affordability in Australia continues to decline, with large increases in residential property values and slow development of well-targeted affordable housing. Therefore, the social housing sector is increasingly under pressure to assist households to access appropriate, secure dwellings. As a result, current demand for social housing is much higher than supply, and waiting lists and times are extensive (Department of the Prime Minister and Cabinet, 2014). 
As a result of limited investment in the sector over many years, social housing in Australia has become 'residualised': increasingly targeted to those with the greatest and most complex needs. This has led to falling rent revenue as the client's capacity to pay has declined, and has created a cycle of stock deterioration and reduction through an ongoing lack of funds for maintenance and new supply of public housing (Queensland Department of Housing and Public Works, 2014). For example, National Shelter has identified a 3.1 per cent decrease in public housing supply between 2006 and 2012 in Australia (National Shelter, 2014). Much of the public rental housing stock is now at the end of its economic life or does not meet current needs. The poor maintenance of dwelling stock can then create stigma and negative stereotyping of social housing tenants (Jacobs et al, 2010). Underutilisation of housing stock has also become a challenge as typical household sizes have decreased and tenants are living in social housing that does not match their household size or needs (New South Wales Auditor-General's Office, 2013).

Around Australia, more social housing is being provided by the community housing sector, with governments increasingly partnering with not-for-profit housing providers to finance, supply and manage affordable housing stock. Figure 2.1 provides an overview of the Australian system in 2014, and the position of social housing within this system. Alternate sources of financing for this sector in Australia are, however, still limited when compared to other countries. In the UK

The European Investment Bank has agreed to provide GBP 1 billion for new social housing investment across the UK in partnership with the Housing Finance Corporation (THFC). The expanded Affordable Housing Finance programme will help to alleviate shortages in affordable housing and accelerate construction of new build social housing. 
On the other hand, in the US, 'Google Inc., Kroger Co. and Waste Management Inc. are investing in low-income rental housing as companies are lured to a field long dominated by financial firms with returns that have doubled to almost 10 percent since 2006' (Gopal, 2010).

Current research at Griffith University School of Business, funded by the National Affordable Housing Consortium, is seeking to develop innovative financial instruments to attract institutional investments into the Australian social housing sector. This project is evaluating the risks and returns of social housing based on advanced and recently developed models and theories in finance, such as the real options model, in order to develop the incomplete financial market for social housing in this country.

Figure 2.2 provides a further breakdown of the social housing sector in Australia.

Australia has a three-tiered system; federal, state and local governments all have a role to play in the availability of social housing. State jurisdictions have traditionally taken a lead role in social housing delivery, for example:

- in Queensland, 75 per cent $(54,394$ out of 72,329$)$ of social housing stock was governmentowned in 2012. This stock was managed through a statewide network involving 23 Housing Service Centres, with the further 25 per cent $(17,935)$ being owned and managed by community housing providers (Queensland Department of Housing and Public Works, 2014). In an ambitious and transformative move, as part of the Housing 2020 strategy, the 
Queensland Government is aiming to transfer 90 per cent of all state-managed dwellings to the community housing sector by 2020 (Queensland Department of Housing and Public Works, 2014);

- in Western Australia (WA), the majority of social housing continues to be managed by the state government. The WA Housing Authority manages approximately 36,000 of the 44,700 social housing properties, with community housing associations in charge of approximately 7,700 additional properties. They also offer an array of products through 'Keystart Home Loans'. 'These loan products help eligible people to buy their own homes through low deposit loans and shared equity schemes. Specific loan assistance is available for public housing tenants, sole parents, people living with a disability and Aboriginal borrowers' (WA Housing Authority, 2015). Access Housing and Foundation Housing are the two largest community housing providers with sufficient assets to leverage funds for growth. Although many smaller players exist, they remain limited in capacity;

- in South Australia, 'community providers manage approximately 13 per cent of South Australia's social housing supply. Existing government commitments will take this to 27 per cent over the next 5 years and initiatives by the community housing sector alongside government support are expected to increase it even further' (Renewal SA, 2013a). As of 2013 there were 48,780 social housing dwellings in South Australia (Renewal SA, 2013b).

Table 2.1 is based on an initial review of the various state-based transformations underway in 2015 to address the provision of social housing. 


\section{The need for information integration}

Housing is a complex good that brings together social, economic and environmental concerns.

(Rosenfeld, 2015)

Rosenfeld highlights the need for clarity around the vision and purpose of social housing, and stakeholders' roles and responsibilities, in light of the continuing trend for the decentralisation of state responsibilities. In addition, she notes the integrative nature of the sector, which requires both the horizontal and vertical integration of efforts and funding across ministries, departments and levels of government with responsibilities such as social services, health and infrastructure. Beyond this, there is also the role of the private and not-for-profit sectors in provision, financing, maintenance and the like. In many countries, this extends to the role of international organisations who are seen 'as the hubs of knowledge exchange' (Rosenfeld, 2015). A further key challenge is to better understand and quantify the broader productivity benefits from investment in social housing, for tenants, the community and the wider economy.

Housing matters bring together numerous sectors and disciplines. If treated as a mere piece of other disciplines, the solutions are unlikely to bring impactful results. Instead, housing should be treated as a sovereign professional discipline that convenes disparate efforts for integrated solutions.

(Rosenfeld, 2015) 
The Australian case study presented in this chapter discusses research exploring the impact of social housing across these various layers, through a productivity lens. This is examined by looking at an array of benefits from tenant, macroeconomic, fiscal and non-economic perspectives. This is a broad-based approach with a focus on practical outcomes requiring an integrated approach across the various levels of government from national to local, to private sector and not-forprofit providers (Figure 2.3).

To achieve this broader understanding, government and industry knowledge, information and data will need to be used in a connected manner to identify productivity benefits and impacts. Tracking the long-term benefits of providing safe and secure housing will be crucial. Rosenthal notes the following initiatives communicated to the UNECE by national and sector leaders in housing include: the development of topic-specific think tanks; capacity building for local authorities; knowledge exchange platforms across the private and public sector; and a commitment to 'housing as an integrative field' (Rosenthal, 2015).

This will require innovative thinking around how information, knowledge and data are gathered to articulate the social along with the economic impact of providing social housing. McCreless and Trelstad (2012) highlight the need to combine 'information from disparate methodologies into a coherent, internally consistent and accurate categorisation of investments by level of social impact' (McCreless and Trelstad, 2012). These authors adopt the triangulation approach to data gathering for assessing social impact.

In addition to basic output metrics, we also include enterprise- or projectreported information, site visits by our staff, case studies and other reports by third parties, 
qualitative and quantitative surveys (including randomized controlled trials), data gathered using new approaches to mobile technology, and literature reviews. We fold in cost data to evaluate cost-effectiveness, and when possible, we gather data to provide a counterfactual to establish causality and attribution.

(McCreless and Trelstad, 2012)

\section{Case study: a productivity-based framework for social housing delivery in Australia}

Current Australian research is seeking to provide a new rationale for policy making, delivery and evaluation of social housing programmes. This includes learning lessons from international best practice. Country-specific financing and delivery mechanisms have, however, evolved out of particular cultural, political, economic, policy, legal and financial frameworks of different countries. This has led to limited options for exploring new directions in the delivery of social housing and limits the established, collective knowledge regarding general principles for best practice.

A central element of the approach being explored is productivity for the individual and for society more broadly. A broad range of relevant housing and non-housing outcomes can be potentially attributed to having safe and stable housing. Examples include higher resident well-being, better employment outcomes, stronger community ties and a sense of safety within a neighbourhood. The integration of information required to demonstrate this is complex, moving across stakeholders and agencies from tenant, to housing provider, to local government, to state government and to the federal government. It also requires significant data integration. The value of this consolidation will require clarification of causal links between outcomes and indicators and determination of the social return on investment. 


\section{The framework}

The 'Strategic Evaluation Framework' for social housing delivery has been developed as part of Australia's Sustainable Built Environment National Research Centre (SBEnrc) project 'Rethinking Social Housing: Effective, Efficient, Equitable' (Kraatz et al., 2015). This framework aims to develop a platform that can be used by policy makers to determine the most effective and beneficial programme delivery options that address housing and non-housing outcomes, all explored through lenses of productivity.

The following case study discusses the development of this framework (Figure 2.4) that explores the benefits and costs of social housing through the four lenses of the tenant, the macro-economic costs and benefits, the fiscal perspective, and the non-economic focus (environmental and social capital).

The tenant benefits include enhanced capacity to engage in education and employment, to improve health and well-being, and to enable social engagement. The macro-economic impacts of housing intervention can include productivity improvements and growth through increased construction activity and greater workforce engagement. Fiscal benefits can include revenue increases if social housing has positive productivity impacts. It also includes potential impacts on government expenditure, such as better health leading to less sick leave and more people working longer, all of which adds to productivity and tax revenues, as well as to higher expenditure on education and training, and stronger engagement with work, stronger self-esteem and adherence to prevailing social mores, leading to lower expenditure on mental health and prisons. The non-economic benefits and returns can flow from improved resource efficiency, greater social capital and neighbourhood relations through a more stable social environment. 
To address this broad context, the framework comprises four elements that integrate data, information and knowledge from diverse sources including:

- outcomes and indicators matrix: drawing on academic, government and industry data across the nine domains of community, economy, education, employment, environment, health and well- being, housing, social, and urban amenity;

- causality and associations: associations and/or causality; it will be necessary to demonstrate links between selected indicators in relation to social housing outcomes;

- return on investment: being able to demonstrate the broader social return on investment in social housing for each of the indicators and outcomes is a complex and essential element of the development of this framework;

- data and datasets: to provide the statistical basis from which to build the framework.

Significant gaps in knowledge are being identified in the course of this research in each of these areas. Highlighting this need and developing methodologies and avenues for addressing these gaps is an integral part of this research.

\section{Outcomes and indicators}

This research has established a provisional set of outcomes, drawn from previous research, and industry stakeholders. The 'outcomes and indicator matrix' is the result of an extensive literature review over a twelve-month period in which the researchers have drawn together previously used 
indicators from different disciplines that have links with social housing. The indicators have been sorted and placed into nine separate domains: employment, education, health and well-being, social, urban amenity, community, environment, economy, and housing objectives.

As part of researching these indicators and developing the matrix, this research has investigated the broad objectives of social housing provision. A key aim of this matrix is to provide both government agencies and community housing providers with the ability to measure outcomes and better articulate the broader community value of providing housing security to all.

The domains, outcomes and indicators have been compiled in a cascade utilising, at the upmost level, the Global Reporting Initiative.2 This has been done to provide universality to the indicators, which intersect various policy and provision domains and to potentially enable them to be more readily aligned with existing organisational reporting. Burke and Hayward (2000) provide a useful example of cascading performance indicators (Table 2.2). They also highlight the need to have indicators for performance at the various levels of service provision in order to deliver indicators that have relevance and validity from a national to an agency or tenant level.

A working set of outcomes and indicators across nine domains has been established in previous research undertaken by the team in 2014-15 (Kraatz et al., 2015). The intention is that this master set of indicators can be drawn upon by different agencies for different cohorts in different geographical locations across Australia. 


\section{Establishing causality and/or associations}

A key challenge for this research is to be able to associate non-housing indicators and data, such as at a neighbourhood, household or individual level, to housing provision, such as types, styles, tenures, locations and conditions, by way of direct or indirect causal connections.

The relationship between housing and the various aspects of productivity being considered is complex, multidirectional and mediated by a host of intervening factors. A strong and logical method, grounded on previous research about the nature of connections between housing and nonhousing domains, is required. To this end, the research team is developing a rigorous and defensible method drawing upon global literature.

Given the strong confirmed causal links between housing and health, the tradition of 'integrated environmental health impact assessment' will be further investigated as a concept to establish

a means of assessing the extent, time trends or spatial distribution of health effects related to environmental exposures, and health-related impacts of policies that affect the environment, in ways that take account of the complexities, interdependencies and uncertainties of the real world.

(Knol, 2010)

The 'Butterfly Model of Health' developed in the late 1990s builds on several previous models and reflects a 30-year trend. Its aim was to 'identify the direct relationships between human health and 
the so-called "determinants of health"' defined as 'factors, whether they be events, characteristics, or other definable entities, that brings about change in a health condition' (VanLeeuwen et al., 1999). This work explored the inter-relationships between the bio-physical and the socio-economic environments on people. This approach is one in a significant body of knowledge that acknowledges the links between social, environmental and health conditions. This tradition for building causal relationships includes the DPSIR framework developed for the World Health Organisation in the 1990s. This acronym stands for driving forces and the resulting environment pressures on the state of the environment and impacts resulting from changes in environment and the societal response to these changes in the environment to establish causal links.

In the UK, the Scottish Government has built upon this tradition to articulate associations between housing and health (The Scottish Government, 2008; 2011) through their modified DPSEEA3 Model for the Good Places, Better Health initiative commenced in 2008 (Scottish Government, 2015). In Canada, Buzzelli (2009) provides an annotated bibliography which explores causal links and/or associations between housing and a variety of non-housing outcomes such as health, education and corrections, at the household, neighbourhood and macro-economic levels. The work of the Housing Associations' Charitable Trust (HACT) in the UK, and the National Housing Conference in the US, will also inform the continuing SBEnrc research.

\section{Return on investment}

Identifying the return on investment (ROI) associated with social housing is driven by the need to better articulate the social and economic returns to the community of investment in social housing. To effectively do this, the research team is developing outcomes and indicators that go beyond the 
traditional specific housing indicators to embrace externalities not typically measured in relation to the investment in social housing itself.

This is important in the current context of social impact measurement being pursued by governments across Australia and internationally. Dunn (2014) defines social impact investing as investing in efforts that not only provide a return on investment, but also target specific social needs. Such measurement is also important in order to attract institutional investment to the delivery of social housing through establishing the expectation (supported by evidence) that investors will recover their money and potentially gain an income stream from the investment (Knowles in Dunn, 2014).

There are many methods through which indirect, non-market values have been quantified in the past. The different methodological approaches have fed into the nature of indicators used for measurement. Two methods for measuring outcomes and potentially determining return on investment have been identified for further research in the context of the strategic evaluation framework (Figure 2.5):

- social return on investment (SROI);

- well-being valuation analysis (WVA).

Both these methodologies have been used and developed in the UK. SROI was adopted to ensure that the potential (non-economic) value added is adequately assessed when determining the placement of funds and choice of service providers (Harlock, 2012). The Public Contracts (Social Value) Act was introduced in 2012. To implement this regulation, an analysis of social value is 
required when determining contract allocation. It provides a policy tool that levels the playing field between third-sector organisations and commercial operators. It does so by placing value on the less tangible, but important outcomes, that third-sector organisations can bring about. The WVA approach draws upon both the SROI method and traditional cost-benefit analysis (Fujiwara, 2014; Fujiwara and Campbell, 2011). Developed specifically for measuring the social value of housing associations in the UK, the method emerged in response to the perceived lack of appropriate tools for quantifying social value on a large, sector-wide scale.

In the Netherlands, social housing provision is monitored using the 'Aedex real estate index' (Bortel and Elsinga, 2007). The index

\begin{abstract}
Measures the profitability of housing associations and the difference between this figure and the profitability that could be achieved by pursuing a commercial strategy. This difference, also called a 'dividend to society' is assumed to be the profitability that housing associations do not realise because of their non-profit character.
\end{abstract}

(Bortel and Elsinga, 2007)

This represents an innovative way of making housing providers financially accountable while still valuing their social impact. In Australia, several studies have adopted the SROI method. Two examples include The Social Value of Community Housing in Australia study (Ravi and Reinhardt, 2011) and that for the Victorian Women's Housing Association (Kliger et al., 2011; Social Ventures Australia, 2010). Kliger et al. adopted the SROI approach to discuss the premise 'that investment in affordable housing for low-income women provides both micro and macro-economic benefits for cities and communities' (Kliger et al., 2011). They examined 'the value produced by the volunteer 
and philanthropic group known as the Victorian Women's Housing Association (VWHA)'. This paper draws on the Social Ventures Australia study reported in 2010 (Social Ventures Australia, 2010).

\section{Data and datasets}

Data for this project is being obtained from several sources including both quantitative and qualitative methodologies (Randolph and Judd, 2001; Moore et al., 2002). Those based on quantitative methodology include official demographic data from Australia's key social security safety net provider, Centrelink; state-based housing agencies or census data (Australian Bureau of Statistics); systematic observations; sample surveys including structured interviews; experimental or quasi-experimental studies; and cost-benefit analyses. Those based on qualitative methodology can be drawn from participant observation; in-depth interviews and surveys; focus groups; action research; and critical or historical analyses.

These outcomes and indicators sit within the broader context of social housing delivery in Australia. Other statistical information (both national and statebased) is required to assist interpretation of the indicators. Data needs to be gathered from several sources including other indicator sets used for specific performance evaluation purposes. It also needs to be studied in conjunction with other statistical reports and national datasets, and over time (due to the longitudinal nature of data required). Some existing datasets that will be used are outlined below. Table 2.3 highlights several national and state-based datasets from which data will need to be drawn in order to consolidate cohort, geographical and longitudinal impacts of policy change with regards to the provision of social housing. 
It is likely that data gaps will also be identified and international knowledge will be drawn on to help identify additional data that may be required to provide an effective picture. In the UK, the Wellbeing Valuation Analysis methodology draws upon several datasets including the British Household Panel Survey; Understanding Society; The Crime Survey for England and Wales; and the Taking Part survey.

These datasets include people's responses to wellbeing questions, and questions on a large number of aspects and circumstances of their lives such as employment status, marital status, health status, whether they volunteer, whether they play sports, whether they live in a safe area, and so on, resulting in a wide range of values.

(Trotter et al., 2014)

In Canada, again several sources of data exist including:

- Statistics Canada for data on population and demographics, dwelling counts, housing and shelter costs, and economic and migration estimates;

- Canada Mortgage and Housing Corporation for customised data on the cost of housing, the availability of housing, vacancy rates and housing Starts and Completions Survey;

- Human Resources and Social Development Canada for minimum wage database;

- The Homeless Individuals and Families Information System;

- Homeless and Social Housing Data.

All such datasets address a unique aspect of the social and economic benefits that flow from safe and secure housing. The intention is that integrated with other more dynamic organisational and 
tenant information and knowledge (McCreless and Trelstad, 2012), such data can help define the impacts and benefits of social housing in the context of the proposed framework.

\section{Concluding remarks}

This chapter has shown that social housing is a global challenge affecting millions of people and requiring the action of a multitude of stakeholders from the public, private and not-for-profit sectors. The need for an integrated approach to address issues across the housing continuum is also demonstrated. The authors have explored the need for the horizontal and vertical integration of data, information and knowledge within and across departments and organisations to achieve a more sustainable social housing system.

This has been explored in a case study from an Australian perspective. The next stage of this case study research is being undertaken through SBEnrc in two parallel parts in order to further develop key aspects of the presented framework. The first part is looking at data integration, being undertaken by Curtin University, with the Western Australian Housing Authority and Access Housing WA, to explore data sharing across government departments and organisations in order to develop a workable framework that can inform policy making and social housing delivery. The second part is investigating the integration of this framework with evolving government performance frameworks in times of fiscal constraint. This is being led by Griffith University, with partners including the New South Wales Land and Housing Corporation, the Queensland Department of Housing and Public Works and the National Affordable Housing Consortium. 
A key challenge in the development of this type of research is managing the complex array of information; particularly when exploring impacts across the nine domains considered important to social housing outcomes in the framework presented in the case study. This complexity cannot be effectively addressed using only traditional approaches focused on the management of supply or demand that do not provide management strategies that meet the underlying needs and values of the affected populations. Further research is also needed into combining Geographic Information Systems (GIS), Bayesian network and system dynamics modelling approach (Sahin and Mohamed, 2013). This recognises that no single current methodology can efficiently and adequately integrate the demand, supply and asset management processes of housing while addressing the associated social, economic and environmental dimensions.

\section{Notes}

1. 1 This is equivalent to USD32,182/year at the average exchange rate for 2015 (EUR1 = USD1.11).

2. $2 \mathrm{GRI}$ is an international independent organisation that helps businesses, governments and other organisations understand and communicate the impact of business on critical sustainability issues such as climate change, human rights, corruption and many other (GRI, 2016).

3. 3 This acronym stands for driving forces, pressures, state, exposures, health effects, actions.

\section{References}

ABS, 2013. Housing occupancy and costs, 2011-12, ABS cat. no. 4130.0. Canberra: Australian Bureau of Statistics. 
AEDES, 2016. Dutch Housing in a Nutshell: Examples of Social Innovation for People and Communities, The Hague: AEDES.

Australian Council of Social Services, 2014. Letter to Senator Mark Bishop, Senate Economic References Committee: Enquiry into Affordable Housing, Canberra: Senate Printing Unit, Parliament House.

Australian Institute of Health and Welfare, 2014. Housing Assistance in Australia, Canberra: Australian Institute of Health and Welfare.

Australian Institute of Health and Welfare, 2016. National Housing Assistance Data Repository. Australian Institute of Health and Welfare. Available at: http://meteor. aihw.gov.au/content/index.phtml/itemld/462772 [Accessed 16 November 2016].

Bortel, G. V. and Elsinga, M., 2007. A network perspective on the organization of social housing in the Netherlands: The case of urban renewal in The Hague, Housing, Theory and Society, 24(1), 3248.

Bourne, R., 2016. The UK doesn't need more social housing - but we do need to build more homes. The Telegraph, 1:27PM GMT 21 January.

Burke, T. and Hayward, D., 2000. Performance Indicators and Social Housing in Australia, paper presented at the Housing Policy and Practice in the Asia Pacific: Convergence and Divergence Conference, Hong Kong, 13-15 July.

Buzzelli, M., 2009. Is it Possible to Measure the Value of Social Housing?, Canada: Canadian Policy Research Network.

Carlson, M., 2014. Alternative Sources of Capital for the Social/Affordable Housing Sector in Canada. Toronto, Canada: Housing Services Corporation. 
Department of the Prime Minister and Cabinet, 2014. Reform of the Federation White Paper: Roles and Responsibilities in Housing and Homelessness, Canberra: Commonwealth of Australia.

Dunn, J., 2014. Social Impact Investing: Good Returns from New Sector. Available at:

http://business.nab.com.au/afr-special-report-social-impact-investing-8140 [Accessed 20 April 2015].

European Investment Bank, 2016. GBP 1 Billion EIB Backing for UK Social Housing. Available at: www.eib.org/infocentre/press/releases/all/2016/2016-100-gbp-1-billioneuropean-investment-bankbacking-for-uk-social-housing.htm?lang=en [Accessed 1 May 2016].

Fujiwara, D., 2014. Measuring the Social Impact of Community Investment: The Methodology Paper, London: Housing Associations Charitable Trust (HACT).

Fujiwara, D. and Campbell, R., 2011. Valuation Techniques for Social Cost-Benefit Analysis: Stated Preference, Revealed Preference and Subjective Well-Being Approaches: A discussion of the Current Issues, London: HM Treasury.

Global Reporting Initiative, 2016. About GRI. Available at:

www.globalreporting.org/information/about-gri/Pages/default.aspx [Accessed 1 August 2016].

Gopal, P., 2010. Returns Up to $10 \%$ on Low-Income Housing Lure Google, Kroger. Available at: www.bloomberg.com/news/articles/2010-10-06/returns-up-to-10-on-low-incomehousing-luregoogle-kroger [Accessed 24 May 2016].

Harlock, J., 2012. Impact Measurement Practice in the UK Third Sector: A Review of Emerging Evidence, Birmingham: Third Sector Research Centre.

Jacobs, K., Atkinson, R., Colic-Peisker, V., Berry, M. and Dalton, T., 2010. What Future for Public Housing? A Critical Analysis, Melbourne: AHURI. 
Kliger, B., Large, J., Martin A. and Standish, J., 2011. How an Innovative Housing Investment Scheme Can Increase Social and Economic Outcomes for the Disadvantaged, paper presented at the State of Australian Cities Conference. Sydney, Australia, 29 November-2 December.

Knol, A. B., Briggs, D. J. and Lebret, E., 2010. Assessment of complex environmental health problems: Framing the structures and structuring the frameworks, Science of the Total Environment, 408, 2785-2794.

Kraatz, J., Mattan, A., Mitchell, J. and Newman, P., 2015. Rethinking Social Housing: Effective, Efficient, Equitable, Brisbane: Sustainable Built Environment National Research Centre. Available at: www.sbenrc.com.au/research-programs/1-31-rethinking-social-housing-effective-efficientequitable-e3/ [Accessed 01 August 2016].

McCreless, M. and Trelstad, B., 2012. A GPS for social impact: Root capital and acumen fund propose a system for program evaluation that is akin to GPS, Stanford Social Innovation Review, Fall, 21-22.

Moore, G. T., Russell, C., Beed, T. and Phibbs, P., 2002. Comparative Assessment of Housing Evaluation Methods: Evaluating the Economic, Health and Social Impacts of Housing, Sydney: AHURI. Moskalyk, A., 2008. The Role of Public-Private Partnerships in Funding Social Housing in Canada, Ontario: Canadian Policy Research Networks.

National Shelter, 2014. Housing Australia Fact Sheet: A Quick Guide to Housing Facts and Figures, Perth: National Shelter.

New South Wales Auditor-General's Office, 2013. Making the best use of public housing. In New South Wales Auditor-General's Report: Performance Audit. Sydney: New South Wales AuditorGeneral's Office.

Queensland Department of Housing and Public Works, 2014. Housing 2020: Delivering a Flexible, Efficient and Responsive Housing-Assistance System for Queensland's Future, Brisbane: Queensland Government. 
Randolph, B. and Judd, B., 2001. A Framework for Evaluating Neighbourhood Renewal-Lessons Learnt from New South Wales and South Australia, paper presented at the National Housing Conference, Brisbane, Australia, 24-26 October.

Ravi, A. and Reinhardt, C., 2011. The Social Value of Community Housing in Australia, Community Housing Federation of Australia, Australia: CHFA, PowerHousing Australia and Bankmecu.

Renewal SA, 2013a. Affordable Housing, Adelaide: Government of South Australia.

Renewal SA, 2013b. South Australia: Housing Affordability: Demand and Supply by Local Government Area, Adelaide: Government of South Australia.

Romans, E. C., 2014. Forms of Housing Tenancy Regimes in Affordable Housing Public Policies in Barcelona, 2007-2014, paper presented at the European Network of Housing Researchers 2014 International Conference, Edinburgh, Scotland, 1-4 July.

Rosenfeld, O., 2015. Social Housing in the UNECE Region: Models, Trends And Challenges, Geneva: United Nations Economic Commission for Europe.

Sahin, O. and Mohamed, S., 2013. A spatial temporal decision framework for adaptation to sea level rise, Environmental Modelling \& Software, 46, 129-141.

Social Ventures Australia, 2010. Victorian Women's Housing Association Investment in Affordable Housing for Women: The Social and Economic Returns, Melbourne: Victorian Women's Housing Association.

The Scottish Government, 2008. Good Places, Better Health: A New Approach to Environment and Health in Scotland: Implementation Plan, Edinburgh, Scotland: The Scottish Government. 
The Scottish Government, 2011. Good Places Better Health for Scotland's Children: Childhood Mental Health and Wellbeing Evidence Assessment, Scotland: NHS Scotland.

The Scottish Government, 2015. Good Places, Better Health. Available at: www.gov.scot/Topics/Health/Healthy-Living/Good-Places-Better-Health [Accessed 01 August 2016]. Trotter, L., Vine, J., Leach, M. and Fujiwara, D., 2014. Measuring the Social Impact of Community Investment: A Guide to Using the Wellbeing Valuation Approach, London: HACT Housing.

Tunstall, R., Lupton, R., Kneale, D. and Jenkins, A., 2011. Teenage Housing Tenure and Neighbourhoods and the Links with Adult Outcomes: Evidence from the 1970 Cohort Study, London: Centre for Longitudinal Studies, Institute of Education, University of London.

UK Department of Communities and Local Government., 2012. Definitions of general housing terms. Available at: https://www.gov.uk/guidance/definitions-of-generalhousing-terms [Accessed 24 May 2016].

US Department of Housing and Urban Development, 2016. HUD's Public Housing Program. Available at: http://portal.hud.gov/hudportal/HUD?src=/topics/rental_assistance/phprog [Accessed 01 July 2016].

VanLeeuwen, J. A., Waltner-Toews, D., Abernathy, T. and Smit, B., 1999. Evolving models of human health toward and ecosystem context, Ecosystem Health, 5(6), 204-219.

WA Housing Authority, 2015. Estimating Unmet Demand for Public and Affordable Housing, paper presented at the National Housing Conference, Perth, Australia, 28-30 October.

Wong, T.-C. and Goldblum, C., 2016. Social housing in France: A permanent and multifaceted challenge for public policies, Land Use Policy, 54, 95-102.

Yates, J., 2013. Evaluating social and affordable housing reform in Australia: Lessons to be learned from history, International Journal of Housing Policy, 13(2), 111-133. 
Young, L., 2015. 140,000 Canadian Families are Waiting for Housing. Here's What the Parties Plan to Do. Available at: http://globalnews.ca/news/2268505/140000-canadian-familiesare-waiting-forhousing-heres-what-the-parties-plan-to-do/ [Accessed 23 May 2016]. 


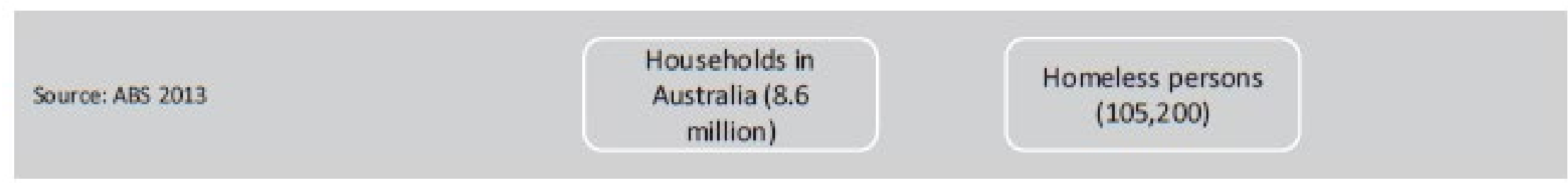

Source: ABS $2013 \quad$ Privately owned (5.8 million) $\quad$ Renting (2.6 million) $\quad \begin{gathered}\text { Tenure type other or not } \\ \text { stated }(200,000)\end{gathered}$

\begin{tabular}{|c|c|c|c|c|c|}
\hline $\begin{array}{l}\text { Ownership/Landlord } \\
\text { Source: ABS } 2013\end{array}$ & $\begin{array}{l}\text { With a } \\
\text { Mortgage } \\
\text { (3.2 million) }\end{array}$ & $\begin{array}{l}\text { Without a } \\
\text { Mortgage } \\
(2.6 \text { million })\end{array}$ & $\begin{array}{l}\text { Private Landlord ( } 2.2 \\
\text { million) }\end{array}$ & \multicolumn{2}{|c|}{$\begin{array}{l}\text { Renting from Government or } \\
\text { Community Housing Organisation } \\
(414,1368) \\
\text { Source: Aaw Housing Assistance Das Repository }\end{array}$} \\
\hline Housing Assistance & \multicolumn{3}{|c|}{ Financial Assistance } & \multicolumn{2}{|c|}{ Social Housing Households } \\
\hline 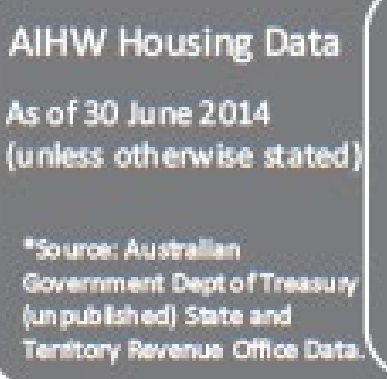 & $\begin{array}{c}\text { Home } \\
\text { Purchase } \\
\text { Assistance } \\
\text { (HPA) } \\
\text { (40,313 } \\
\text { households) }\end{array}$ & $\begin{array}{c}\text { First Home } \\
\text { Owner } \\
\text { Grants } \\
\text { (FHOG) } \\
(92,315 \\
\text { recipients*) }\end{array}$ & $\begin{array}{l}\text { Private Rent Assistance } \\
\text { (RPA) (118,100 } \\
\text { recipients) } \\
\text { Commonwealth Rent } \\
\text { Assistance (CRA) } \\
\text { (1.3 million recipients) }\end{array}$ & $\begin{array}{l}\text { Public Housing } \\
\text { (321,213) } \\
\text { State owned } \\
\text { and Managed } \\
\text { Indigenous } \\
\text { Housing } \\
\text { (SOMIH) } \\
(9,820)\end{array}$ & $\begin{array}{l}\text { Mainstream } \\
\text { Community } \\
\text { Housing } \\
(65,632) \\
\text { Indigenous } \\
\text { Community } \\
\text { Housing } \\
(17,473)\end{array}$ \\
\hline
\end{tabular}

Figure 2.1 Overview of the housing system in Australia and data sources, at 30 June 2013 (Australian Institute of Health and Welfare, 2014). 


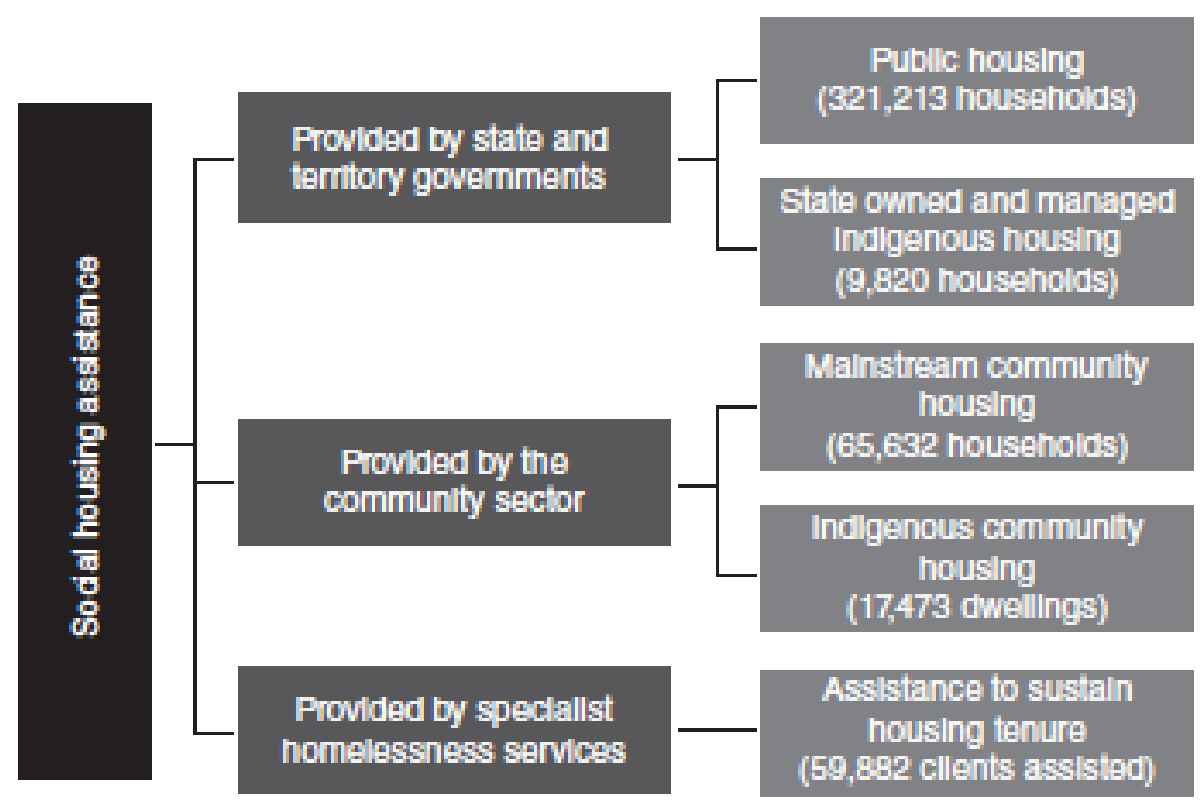

Figure 2.2 Main social housing assistance programmes in Australia and total number of households/clients assisted per programme, 30 June 2013 (Australian Institute of Health and Welfare, 2014). 
Table 2.1 State-by-state transformation matrix

\begin{tabular}{|c|c|c|c|c|c|c|}
\hline Principle/Policy/Practice ${ }^{1}$ & SA & QLD & WA & NSW & VIC & TAS \\
\hline $\begin{array}{l}\text { Housing continuum - crisis - social - private } \\
\text { rental to home ownership \& 'optimum point' }\end{array}$ & $\mathrm{Y}$ & $\mathrm{Y}$ & $\mathrm{Y}$ & $\mathrm{Y}$ & $\mathrm{Y}$ & $\mathrm{Y}$ \\
\hline $\begin{array}{l}\text { Common register (integrated system multi } \\
\text { provider, multi option) }\end{array}$ & $\mathrm{Y}$ & Y & Y & Y & Y & Y \\
\hline Duration of need in social housing & & Y & Y & & & Y \\
\hline Reducing under-occupancy & & $\mathrm{Y}$ & Y & & & \\
\hline Private rental brokerage/assistance & $\mathrm{Y}$ & Y & Y & Y & Y & Y \\
\hline Re-alignment of housing portfolios & $\mathrm{Y}$ & Y & Y & Y & Y & Y \\
\hline Asset transfer & Y & $?$ & Y & Y & Y & $?$ \\
\hline Management transfer ${ }^{2}$ & Y & $\mathrm{Y}^{3}$ & Y & Y & Y & Y \\
\hline Urban renewal & Y & Y & $?$ & Y & Y & Y \\
\hline Public/Private Partnerships & $?$ & Y & Y & Y & Y & Y \\
\hline $\begin{array}{l}\text { Housing impact statements - major } \\
\text { developments }\end{array}$ & & & Y & & & \\
\hline Model planning policies & & & Y & & & \\
\hline Inclusionary zoning & Y & & $Y^{4}$ & & & \\
\hline $\begin{array}{l}\text { Not for Profit/housing organisations - viable } \\
\text { partners } 5 \text { plus companion/support }\end{array}$ & Y & Y & Y & Y & Y & Y \\
\hline
\end{tabular}

Compiled by the research team in 2015

Notes:

1 List based on terminology from WA Government Affordable Housing Strategy 2010 document.

2 Housing ministers' 2009 agreement for up to 35\% transfer of management by 2014. Indigenous housing included. Only Tasmania has reached target thus far.

3 Qld 90\% transfer of management by 2020.

$415 \%$ minimum affordable housing only on government land and housing developments.

5 The impact of the 2014 federal Budget, which cut the final round (\$1 Billion) of NRAS grants, remains unclear. 


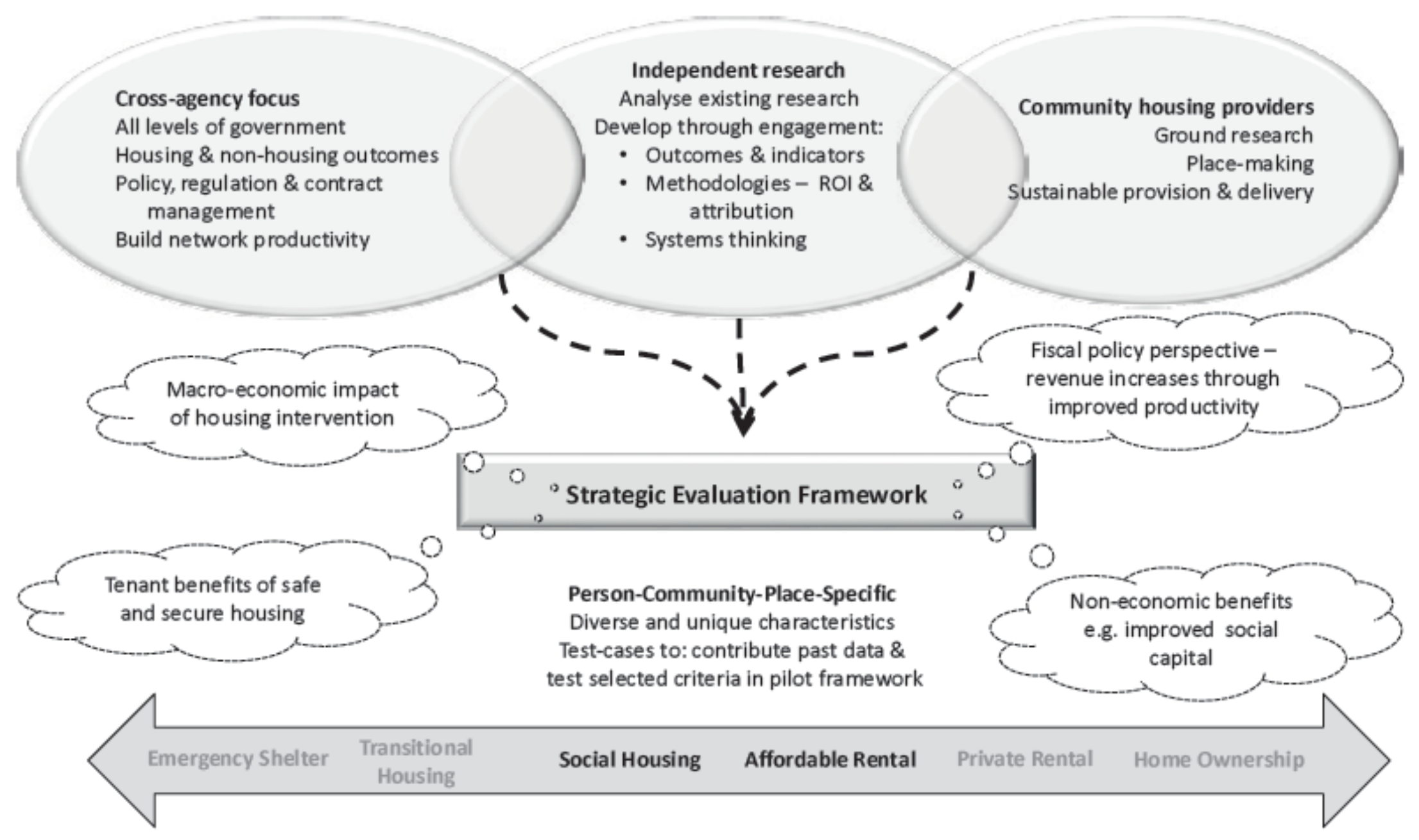

Figure 2.3 Integrating broad-based stakeholder perspectives 


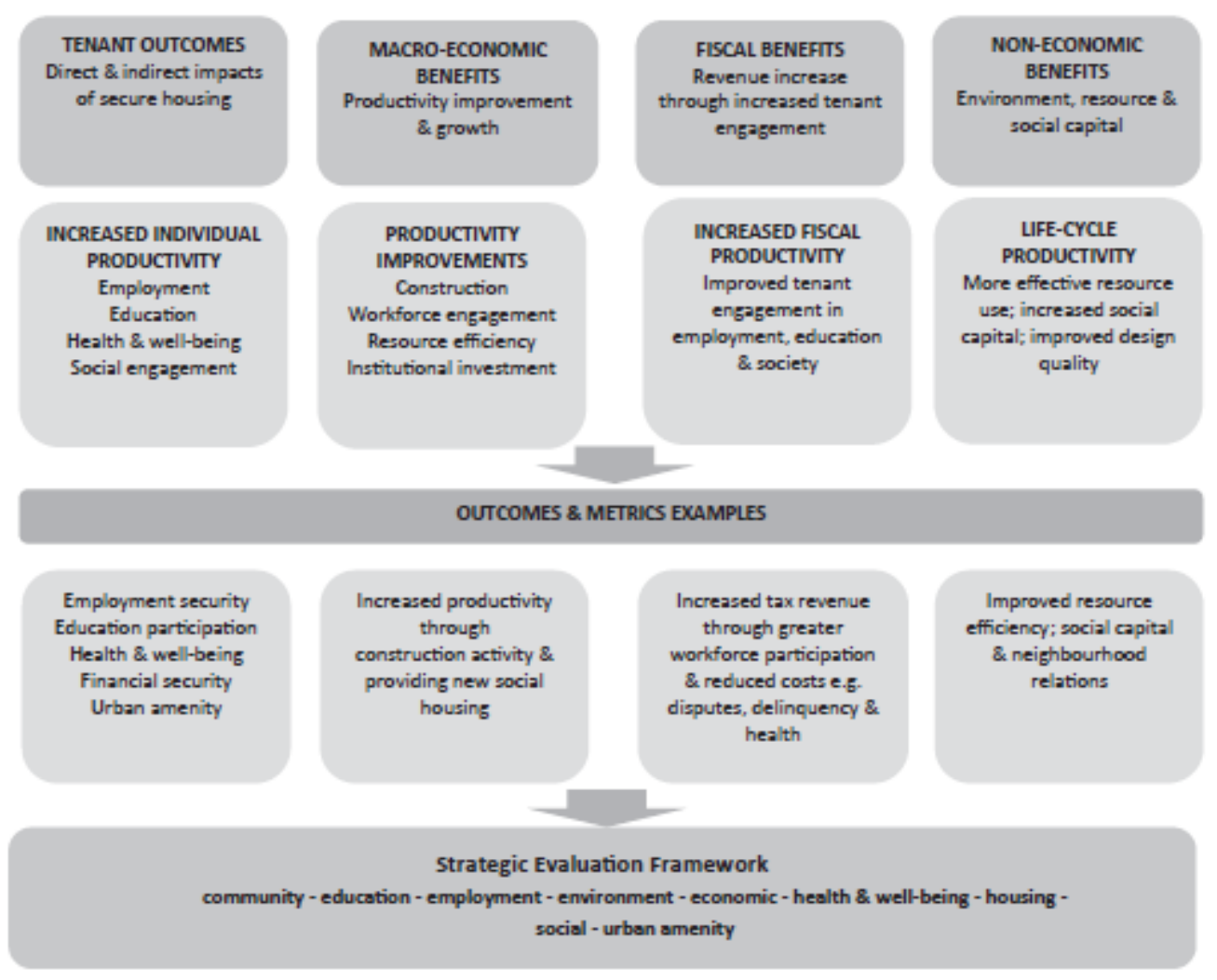

Figure 2.4 Strategic evaluation framework. 
Table 2.2 Layers of performance indicators

\begin{tabular}{ll}
\hline Level & Purpose \\
\hline National & $\begin{array}{l}\text { How well is social housing meeting its objectives? How well are } \\
\text { social housing agencies performing? How does the performance of } \\
\text { social housing agencies compare with other sectors, for example, } \\
\text { private rental sector? } \\
\text { How well is the agency or federation (of agencies) meetings its } \\
\text { objectives? How does its performance compare with other like } \\
\text { State Housing Agency }\end{array}$ \\
organisations? \\
State Housing Agency \\
Business Unit & $\begin{array}{l}\text { example, housing finance, stock production, rental housing } \\
\text { management? }\end{array}$ \\
SHA Regional offices & $\begin{array}{l}\text { How well is a particular region performing, either overall or for a } \\
\text { specific functional business? }\end{array}$ \\
SHA Work unit (teams) & $\begin{array}{l}\text { How well is a work unit achieving its objectives? How does its } \\
\text { performance compare with other similar work units? }\end{array}$ \\
SHA employee & Does the individual's work performance meet agreed targets?
\end{tabular}

Source: Burke and Hayward, 2000. 

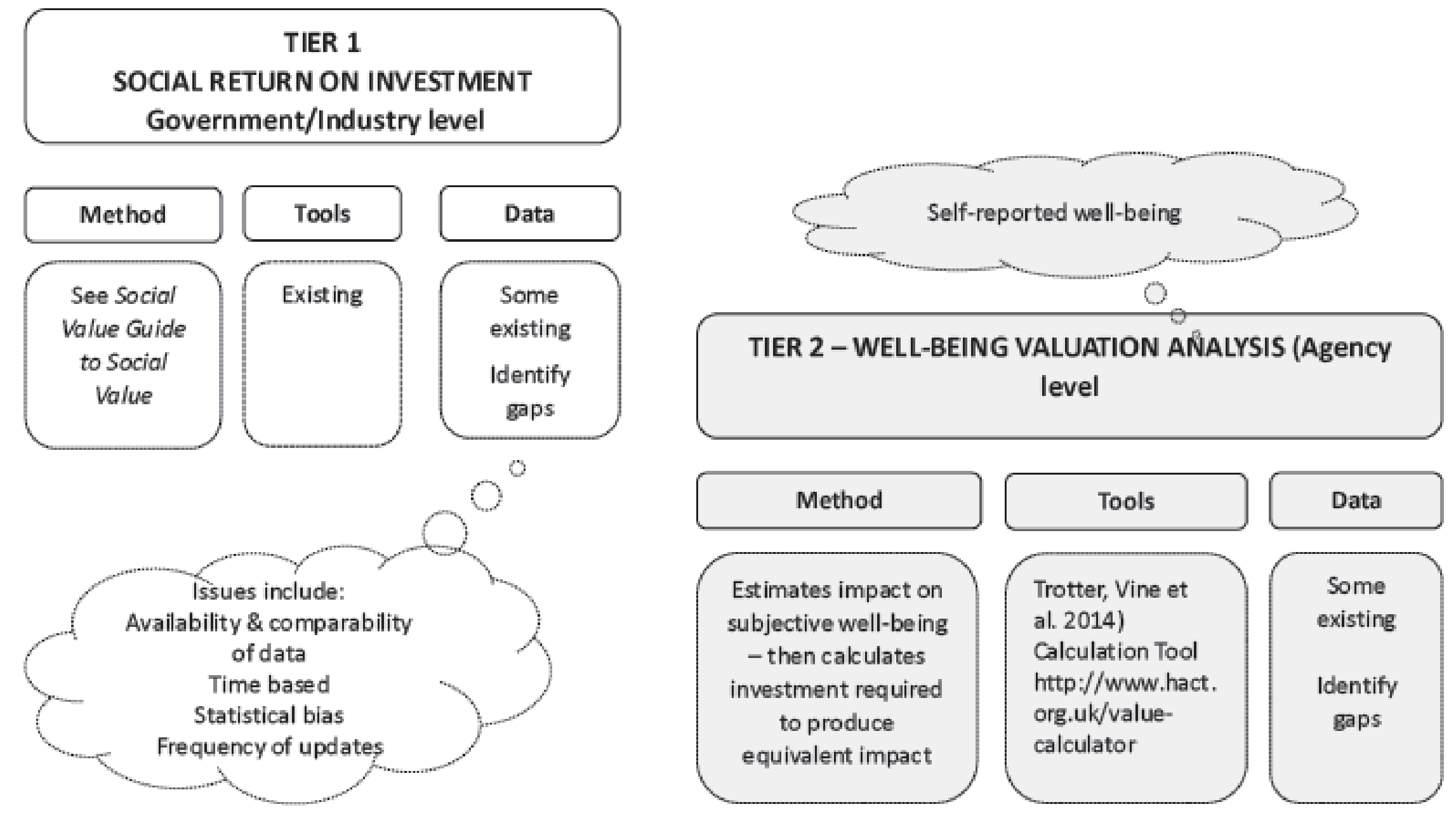

Figure 2.5 Two-tiered approach to return on investment. 
Table 2.3 Some relevant datasets

\begin{tabular}{|c|c|}
\hline Source & Explanation \\
\hline Household, Income and Labour & To support research questions falling within three broad areas \\
\hline Dynamics in Australia (HILDA) & ne dynamics, labour market dy \\
\hline Survey & dynamics. \\
\hline $\begin{array}{l}\text { National Social Housing Survey } \\
\text { (NSHS) }\end{array}$ & Includes tenant satisfaction metrics \\
\hline \multirow[t]{2}{*}{$\begin{array}{l}\text { Australian Bureau of Statistics } \\
\text { (ABS) data }\end{array}$} & $\begin{array}{l}\text { Australian Census of Population and Housing; Survey of Income } \\
\text { and Housing Costs; National Health Survey; Rental Investors }\end{array}$ \\
\hline & $\begin{array}{l}\text { Survey; Disability, Aging and Carers Survey; Mental Health and } \\
\text { Wellbeing of Adults survey; Time Series profile (TSP) DatePack; } \\
\text { Survey of Housing Occupancy and Costs 2009-10, ABS, } 2011 \\
\text { Canberra }\end{array}$ \\
\hline $\begin{array}{l}\text { Australian Institute of Housing } \\
\text { and Wellbeing (AIHW) }\end{array}$ & $\begin{array}{l}\text { Housing assistance in Australia 2011, } 2012 \text { \& 2014. This } \\
\text { provides relevant demographic data. For example, almost 40\% } \\
\text { of social housing households have a person with a disability, } \\
\text { age and sex distribution; National Social Housing Survey - A } \\
\text { summary of national results } 2012\end{array}$ \\
\hline Comm & Relates to Indigenous Community Housing not "Community \\
\hline $\begin{array}{l}\text { Infrastructure Needs Survey } \\
\text { (CHINS) }\end{array}$ & Housing" in the general \\
\hline AURIN - The Australian Urban & able in the AURIN \\
\hline Rese & Porta \\
\hline Network (AURIN) Portal & $\begin{array}{l}\text { Australia, from health and well-being, to economic metrics and } \\
\text { environmental indicators }\end{array}$ \\
\hline Develop & Investigates pathways to health and wellbeing, education, \\
\hline & somily, crila abuse ana negiect, ana juvenile aelinquen \\
\hline Child Health Res & outcomes among Western Australian children and youth. \\
\hline
\end{tabular}

